\title{
Botanical Composition Determination of Range Herbivore Diets: A Review
}

\author{
JERRY L. HOLECHEK, MARTIN VAVRA, AND REX D. PIEPER
}

\begin{abstract}
Procedures used for estimating the botanical composition of the range herbivore's diet include diet observation, utilization techniques, fistula sampling, and fecal analysis. Each of these procedures has important limitations. Direct observation requires minimal time and equipment inputs but accuracy and precision are a problem, particularly with wild animals. Utilization studies are generally unsuitable when plants are actively growing and more than one herbivore is using the area under study. Fistula methods are accurate but are difficult to use with wild animals. In addition they are costly and require considerable time. The esophageal fistula is preferable to the rumen fistula because it provides more accurate information and requires less labor. Stomach analysis involves animal sacrifice and, therefore, is generally restricted to wild animals with large populations. However, trocar sampling of the rumen contents is a new method that avoids this problem. Fecal analysis has been used extensively in recent years to evaluate diet botanical composition of wild herbivores. This procedure gives good precision but accuracy is a problem because of differential digestion between plant species. Techniques are available that can be used to reduce this source of error. Microhistological analysis has become the most widely used method for quantifying botanical composition of masticated forage or fecal material. Recent studies show microhistological analysis can give an accurate representation of percent diet botanical composition by weight if observers use had compounded diets to check their accuracy. A new procedure, infrared spectrophotometry, may have considerable potential for evaluating herbivore diet botanical composition of fistula or fecal samples.
\end{abstract}

In the past 30 years considerable information has been collected by various methods on the botanical composition of the grazing animal's diet. A comprehensive review of these studies is provided by Van Dyne et al. (1980). Knowledge of range herbivore food habits is essential for efficient range management. This information is required for optimal forage allocation to different types of herbivores, selecting types of grazing animals compatible with the forage resource, selecting species for reseeding deteriorated ranges, predicting the outcome of overgrazing by different animals, identifying new species on which to base management, and determining the suitability of exotic animals for a particular range type. Presently knowledge of range herbivore food habits is far from complete, and much more information will be needed in the future if range management effectiveness is to be improved. In the last few years the information on methodology for studying range herbivore food habits has substantially increased. Procedures used to evaluate the botanical composition of the grazing animals' diet have included direct observation of the animal, utilization techniques, stomach analysis, fecal analysis and fistula techniques. The

Jerry L. Holechek and Rex D. Pieper are assistant professor and professor of range science, Department of Animal and Range Sciences, New Mexico State University, Las Cruces 88003. Martin Vavra is associate professor of range nutrition, Oregon State University, Eastern Oregon Agricultural Research Center, Union 97883.

This report is Journal Article 781, Agr. Exp. Sta., New Mexico State University, Las Cruces 88003 .

Manuscript received June 27, 1980. purpose of this review was to consider these procedures emphasizing the more recent information.

\section{Utilization Techniques}

Utilization is one of the oldest approaches used to evaluate the grazing animal's diet. The advantages of this approach include speed and the fact it provides information on where and to what degree a range is being used. When a forage species was used and how often a forage species was used are questions that this approach will not answer. A serious problem with any utilization technique is that large scale losses of plant parts from weathering, trampling and animals other than those of interest can greatly confound results (Cook and Stoddart 1953). Further when forage is actively growing, regrowth after defoliation can make accurate estimates of utilization difficult to obtain. Studies comparing utilization data with fistula samples have shown lack of agreement between the two procedures (Lesperance et al. $1960 \mathrm{~b}$, Ridley et al. 1963, Conner et al. 1963, Laycock et al. 1972, McInnis 1977). Data from these studies and Cook and Stoddart (1953) indicate that when forage is actively growing and/or use is by more than one herbivore, any utilization technique has severe limitations. Under these conditions other procedures in most cases should be selected for determination of diet botanical composition.

Reviews of the various utilization techniques for estimating diets of grazing animals are given by Smith et al. (1962) and Martin (1970). Edlefsen et al. (1960) provide a description of these procedures. Approaches to utilization have involved evaluating differences between grazed and ungrazed plots; evaluating differences before and after grazing; measurement: correlation and regression of factors related to utilization; and general observations and comparisons with predetermined standards of use. The most commonly used methods have been the ocular estimate method of Reid and Pickford (1941) and caged plots. Visual appraisals of forage species use are compared to known values of hand clipped plants with the ocular estimate methods. Caged plot methods involve comparing the amount of herbage present inside a cage with that outside. The major problem with this procedure is that microclimate can be changed by the use of cages (Grelen 1967, Owensby 1969). However, Heady (1957) found these changes were relatively small when open-mesh wire cages were used on annual range in California. Laycock et al. (1972) reported that the caged plot method gave results that were less consistent with data from esophageally fistulated sheep than the ocular estimate method.

\section{Direct Observation of the Animal}

A widely used procedure in past and present studies of herbivore diet botanical composition is direct observation of the grazing animal. Information on this procedure is reviewed by Bjugstad et al. (1970), Theurer (1970), and Theurer et al. (1976). Simplicity, minor equipment requirements and ease of use are major advantages of direct observation. Difficulty in species identification and quantification of how much of a plant was consumed are important problems associated with the procedure. 
Quantitative information from direct observation has been obtained from the bite-count and feeding minutes approaches. When the feeding minutes approach is employed, time spent grazing each species is quantified and assumed to be proportional to the importance of the species in the diet (Bjugstad et al. 1970). The bite-count procedure differs in that number of bites taken from each species, rather than the length of grazing time, is recorded (Reppert 1960). Free et al. (1971) modified the bite-count approach by quantifying the weight per bite of primary forage species in the diet. Species data were then converted to relative percentages by weight. Regelin et al. (1974) reported small differences between percentage of bites and percentage weight converted from bites for several forage species consumed by cattle.

Wild animals are often difficult to locate and approach closely enough for accurate observation. These problems are reduced or eliminated with tame animals. However, only one animal can be observed at a particular time even with tame animals. In addition it may be difficult to differentiate between mere nibbling and active grazing (Bjugstad et al. 1970). There are other problems associated with using tame animals. Diet selection is a complex behavioral act that is influenced by several factors (Krueger et al. 1974). Physiological condition, degree of hunger, topography, other animals present and past grazing experience all influence which and how much of individual plant species are consumed. The previously mentioned factors can be severely altered by using artificially reared and maintained animals.

Two studies have shown that results from direct observation of tame animals were consistent with data from esophageally fistulated animals (Free et al. 1971, Sanders et al. 1980). However, Sanders et al. (1980) reported that direct observation was not practical for use on large brush infested pastures with rough terrain. Data from rumen fistula samples and direct observation differed considerably in a study conducted by Galt et al. (1969) in Arizona.

Factors influencing the accuracy and precision of the direct observation procedure include the degrec of training of the observer, complexity of the plant community present, and/or phenological development of individual plants. Plant identification is much less of a problem on desert rangelands where plants are widely spaced than on prairie ranges where plants are close together. As plants mature, they also become easier to identify. Free et al. (1971) reported the least consistency between direct observation and data from esophageally fistulated cattle in the spring when plants were beginning growth.

\section{Stomach Analysis}

A common procedure used by wildlife researchers is stomach and intestinal tract analysis (Chippendale 1962, Talbot and Talbot 1962, Chamrad and Box 1964, Korschgen 1966, Chamrad and Box 1968, Smith and Shandruk 1979). The main disadvantage of this procedure is that it involves sacrifice of animals and, therefore, is restricted primarily to wild animals with large populations. Other important disadvantages are that differential destruction of forage species during digestion alters the proportions of the food items consumed (Norris 1943, Courtright 1959, Bergerud and Russell 1964, Scotter 1966, McInnis 1977, Vavra and Holechek 1980), and the location of consumption cannot be determined. There may be considerable difficulty in identification of partially digested food items (Hill 1946, Martin 1949, Brown 1961, Anderson et al. 1965). Stomach analysis will provide information on what species are being consumed and gives an indication of relative proportions consumed.

Tabulation of food item numbers, tabulations of frequency of food item occurrences, volumetric measurement, and weight measurement are methods that have been used to evaluate stomach contents (Medin 1975). There is some question concerning which of these methods is best. Chamrad and Box (1964) described a method for quantifying species composition by volume which appears to be superior to other methods in speed, accuracy, and precision. The microhistological technique of Sparks and Malechek (1968) and the microscope point technique of Heady and Van Dyne (1965) can be used to evaluate species composition by weight.

A method recently reported by Wilson et al. (1977) can be used to avoid the problem of animal sacrifice when stomach analysis is used to sample large ruminant diets. Tranquilization is used to immobilize animals, and rumen samples are taken with a trocar. After sample collection the resulting wound is sewn shut. Layering of rumen contents, effective tranquilization of animals, and infection by parasites are problems associated with trocar sampling. Because death from parasites, disease, and overdosing occur often, this technique should not be used on rare or endangered species.

\section{Fecal Analysis}

In the past 10 years, fecal analysis has received greater use for evaluating range herbivore food habits than any other procedure. Fecal analysis has several unique advantages which account for its popularity as a research tool. These are discussed by Croker (1959), Ward (1970), Anthony and Smith (1974), and Scotcher (1979). Advantages of fecal analysis are:

1. It does not interfere with the normal habits of the animals.

2. It permits practically unlimited sampling.

3. It places no restriction on animal movement.

4. It has particular value where animals range over mixed communities.

5. It is the only feasible procedure to use when studying secretive and/or endangered species.

6. It can be used to compare the diets of two or more animals at the same time.

7. Actual sampling requires very little equipment.

However, fecal analysis also has some important disadvantages which are discussed by Ward (1970), Slater and Jones (1971), Owen (1975), Scotcher (1979), Smith and Shand ruk (1979), Vavra and Holechek (1980), and Sanders et al. (1980). These include:

1. Accuracy is a problem because forage species passed in the feces are often not proportional to those consumed.

2. Preference indices cannot be accurately assigned because where the food was consumed cannot be determined.

3. Identification of feces may be a problem. However, Howard (1976) reported procedures involving $\mathrm{pH}$ analysis that can be used to differentiate between animals with similar feces.

4. Considerable equipment and labor are required for actual analysis.

5. An extensive reference plant collection is required.

6. An observer must have considerable training in order to accurately identify plant fragments.

7. Many plant species are difficult to separate at the species and sometimes at the genus level.

8. Plant identification is both tedious and time consuming.

9. Destruction of some plant species may occur during slide preparation (Vavra and Holechek 1980).

10. Procedures of sample collection may bias the results.

11. Some species may become unidentifiable in the feces (Slater and Jones 1977).

12. Identification is further complicated by aging of fecal material before sample collection.

13. Fragmentation may differ between species during digestion so the relative proportion of species appears different.

The previous listing of fecal analysis disadvantages indicates that accuracy is the greatest overall limitation.

Vavra et al. (1978) compared esophageal fistula and fecal samples of cattle on shortgrass range in northeastern Colorado. They found that during the growing season fecal sampling tended to underestimate the percentage of forbs and overestimate the 
percentage of grasses in the diet compared to fistula sampling. The two procedures were more comparable in the winter months when plants were dormant. Esophageal, rumen, and fecal samples from sheep fed known diets were compared to the actual diet in a study by McInnis (1977). Fecal samples were significantly lower in their composition of forbs than the actual diet, and they did not represent the actual diet as well as esophageal and rumen samples.

Smith and Shandruk (1979) used rumen contents, intestinal feces, site feces, and utilization to evaluate the diet of pronghorn antelope. Both intestinal and site feces had fewer plant species than rumen contents. Mule deer were fed known diets in a further test of the accuracy of fecal analysis. Forbs were underestimated while grasses and forbs were overestimated. Other studies showing lack of agreement between known diets or stomach contents and those determined by fecal analysis include Storr (1961), Stewart (1967), Zyznar and Urness (1969), Free et al. (1970), Slater and Jones (1971), Jacobs (1973), Dunnet et al. (1973), Westoby et al. (1976) and Kessler et al. (1981). However not all studies have shown that fecal samples misrepresented the actual diet. Hansen (1971) reported good agreement between composition of ingested and fecal material but no data on plant species were included. Although certain species were consistently either under-or-over-estimated depending on the animal and season, Casebeer and Koss (1970) claimed close similarity between stomach contents and fecal material of wildebeest, zebra, and cattle. Johnson and Pearson (1981) reported high similarity between esophageal fistula and fecal samples from cattle in Louisiana although there was a tendency for forbs to be underestimated.

Microdigestion techniques have recently been used to study differential destruction of plant species during passage through the digestive tract. Investigations by Deardon et al. (1975) and Vavra and Holechek (1980) evaluated the percent weight composition of hand-compounded diets subjected to microdigestion. The microhistological technique of Sparks and Malechek (1968) was used for diet analysis in both studies. There was considerable difference in estimated and actual diets in both studies. However, in each study, the investigators solved the accuracy problem by developing regression equations to correct estimated percent weight to the actual percent weight. Aguirre-DeLuna et al. (1981) found that microhistological analysis did not accurately indicate the percent weight composition of hand compounded diets. However, subjecting the samples to microdigestion greatly improved accuracy. The species evaluated in their study apparently would not require correction factors if fecal analysis was used. When fecal analysis is used in ruminant diet quantification, sufficient plant material should be collected so that hand compounded mixtures can be made and digested in vitro (Vavra and Holechek 1980). Bias due to differential digestion can be reduced by developing regression equations between estimated and actual values for bias correction. In vivo trials would be required to correct for this type of bias in non-ruminants. Less bias would be expected with non-ruminants because they are less efficient in fiber digestion.

Presently little information is available on the precision of fecal analysis. Research reported by Anthony and Smith (1974) indicated that 15 fecal samples would give the same level of precision as 50 deer rumen samples. They considered 15 to be the minimum fecal sample number that should be used to evaluate deer diets during a particular season at a particular location. Further study is needed regarding the precision of fecal sampling.

\section{Fistula Techniques}

Esophageal and rumen fistula techniques have considerable advantage over the sampling methods previously discussed because they enable the investigator to obtain naturally grazed samples. Both fistulas have been widely used (Theurer et al. 1976). However, the esophageal fistula is generally preferred over the rumen fistula because rumen evacuation subjects animals to abnormal physiological conditions, is limited to large animals, and is more laborious (Rice 1970). Esophageal fistula samples have been found to be more representative of known diets than rumen samples. One advantage that rumen sampling does have over esophageal sampling is that the rumen sample contains all the forage consumed during the collection (Rice 1970). The esophageal fistula can become plugged allowing material to pass through the rumen or forage can be lost from collection bags which are required with the esophageal fistulated animal. Reviews regarding the development and use of the esophageal fistula include those of Van Dyne and Torrell (1964), Theurer (1970), Rice (1970), Campbell et al. (1968) and Theurer et al. (1976). Surgical techniques of esophageal fistulation for largc animals arc described by Torrell (1954), Cook et al. (1958, 1963), Hamilton et al. (1960), McManus (1962a), McManus (1962b), and Chapman and Hamilton (1962). Information on surgery success and maintenance has been reported by Torrell (1954), Cook et al. (1958), Lesperance et al. (1960a), Cook et al. (1963), Van Dyne and Torrell (1964), Jefferies and Rice (1969), and Lake and Clanton (1972). Closure devices for esophageal fistulas are discussed by Holechek et al. (1982b). The care of esophageally fistulated animals is discussed by Cook et al. (1958) and Hoehne et al. (1965). Holechek (1982b) reported that fistulated animals could be used for several years when given adequate care.

Problems associate with the use of the esophageal fistula include contamination by rumen contents, incomplete recoveries, high cost, and low sampling precision for individual species in the diet. The effect of saliva on the chemical composition of ingested forage is reviewed by Holechek et al. (1982b). Holechek (unpublished) found no differences between several hand compounded diets fed to esophageal fistulated cattle and the actual botanical composition of the diets. Studies conducted by Grimes and Watkins (1965) and Campbell et al. (1968) showed that esophageal fistula sample recovery ranged from 35 to $94 \%$. Holechek (1980) reported few recovery problems when the closure device described by Bedell (1968) was used.

Samples contaminated by rumen contents cannot be used for botanical analysis. Bath et al. (1956) reported that collection periods of longer than 30 minutes increased the chance of regurgitation of rumen contents into the collection bag. However the present authors have found this problem is primarily related to time since previous eating. Withholding feed from animals for a few hours will usually overcome this problem.

Several studies have shown that estimates of diet botanical composition obtained with esophageally fistulated animals are low in precision (Van Dyne and Heady 1965, Galt et al. 1969, Galt 1972, Harniss et al. 1975, Holechek 1980). Van Dyne and Heady (1965) calculated 24 or more animals would be required to estimate major species with adequate precision $(90 \%$ confidence the estimate is within $10 \%$ of the mean). At the forage class level (grass, forb, browse) as many as ninc animals were required for the same precision level. Galt et al. (1969) found that 30 steers would be needed to adequately ( $90 \%$ confidence, $10 \%$ of the mean) sample important species on desert grassland range in Arizona. Even higher numbers were required for major species to be within $10 \%$ of the mean with $90 \%$ confidence in studies conducted by Galt (1972), Harniss et al. (1975) and Holechek (1980). It a ppears impractical to estimate content of individual species in the diet to a close degree of precision because of the large number of animals required.

\section{Botanical Analysis of Fistual Samples}

Reviews on the various methods of determining the botanical composition of fistula samples include Theurer (1970), Ward (1970), and Theurer et al. (1976). These methods can be categorized into the basic groups of visual appraisal, manual separation with weight or volume analysis, microscope point methods, and microhistological methods (Theurer et al. 1976). Only the techniques involving the use of microscope provide a quantitative evaluation diet botanical composition (Theurer et al. 1976). Visual analyses 
can be used to identify most browse plants but grasses and forbs are generally masticated beyond recognition (Cook et al. 1958). After reviewing studies involving manual separation of plants into major groups or specific species (Hoehne et al. 1967, Obioha 1967), Theurer et al. (1976) concluded this procedure was low in precision and time consuming. For these reasons the microscope point and microhistological techniques have become the most widely used methods for botanical analysis of diet samples. The two techniques are differentiated by sample preparation procedures, plant quantification procedures, and the degree of microscope magnification used in plant fragment identification.

In a review Theurer et al. (1976) reported the microscope point technique was first used by Levy and Madden (1933), further developed by Heady and Torrell (1959), and illustrated by Harker et al. (1964). This technique involves spreading clipped fistula forage over a tray. The tray is then passed under a microscope with $16 \times$ magnification with cross hairs and established stops. The plant that occurs under the crosshairs is identified and recorded for 100 different point locations. Percent composition by weight is estimated from point data by regression equations. Several modifications of the basic method previously discussed have been used to evaluate diet botanical composition (Chamrad and Box 1964, Van Dyne and Heady 1965, Galt et al. 1969, Durham and Kothmann 1977).

A summary of precision and reliability estimates for microscope point analysis is given by Theurer et al.(1976). Studies have shown that consistency between observers was high when the microscope point technique was used to quantify known diets. Different observers were consistent in estimating the amounts of different plant species in known mixtures in studies conducted by Harker et al. (1964) and Galt et al. (1968).

Because a $1: 1$ ratio does not exist between percent points observed and percent weight (Heady and Van Dyne 1965, Harker et al. 1964, Galt 1972), reg ression equations a re developed between these two parameters by feeding and analyzing known diets. In all the studies reviewed by Theurer et al. (1976) the correlation coefficient $(r)$ was .85 or greater which shows that the percent points can be accurately used to predict botanical composition by weight. Theurer et al. (1976) reviewed resea rch conducted by Galt (1972) which showed that the relationship between the percent volume and the percent points was stronger than the relationship between the percent weight and the percent points. Relating volume, rather than weight, to points may be better for quantifying diets because the regression equations are less dependent on the species composition of the mixture (Theurer et al. 1976).

Baumgartner and Martin (1939) first described the microhistological technique which was later refined by Dusi (1947), Sparks and Malechek (1968), Voth and Black (1973), and Holechek and Gross (1982b). The technique, as demonstrated by Sparks and Malechek (1968), involves oven drying and then grinding diet samples through a $1-\mathrm{mm}$ screen to reduce all fragments to a uniform size. Five slide mounts are then prepa red for each diet sample using Hertwig's clearing solution (Baumgartner and Martin 1939) and Hoyer's mounting solution (Baker and Wharten 1952). After drying at $60^{\circ} \mathrm{C}$, the slides are analyzed under a compound binocular microscope. Twenty microscope fields under a $125 \times$ magnification are read for each slide. Epidermal fragments other than hairs are recorded as presence of the plant species on the slide. The percent frequency is calculated for each species in the mixture, and the table developed by Fracker and Brischle (1944) is used to convert frequency to density. Relative density and relative percent dry weight can be assumed to have a 1:1 regression ratio on the basis of the plant species used in the study by Sparks and Malechek (1968).

A number of studies are now available which have examined the relationship between observed and expected values for known mixtures when microhistological analysis was used to estimate species composition by weight (Denham 1965, Sparks and Malechek 1968, Westoby et al. 1976, Vavra and Holechek 1980, Holechek and Gross 1982a). These studies, with the exception of
Westoby et al. (1976), have shown that correlations coefficients $(r)$ between expected and observed values to be greater than .95 . The investigation conducted by Holechek and Gross (1982a) is the most intensive examination of this relationship. They used 26 handcompounded mixtures containing various combinations of grasses, forbs and shrubs from semidesert range. The regression equations developed in their study agreed quite well with those of Sparks and Malechek (1968). The study conducted by Holechek and Gross (1981a) differed from other studies in that observers were given special training with hand compounded diets prior to analysis of the test mixtures and observers were replicated.

A 1:1 relationship between relative density and relative percent composition by weight does not exist for all plant species (Westoby et al. 1976, Havstad and Donart 1978, Vavra and Holechek 1980, Holechek 1982, Holechek et al. 1982a). Studies by Havstad and Donart (1978) and Holechek (1982) showed that ratios of identifiable to nonidentifiable fragments and ratios between grasses, forbs and shrubs were not equal to one. Holechek (1982) found that sample preparation techniques influenced both accuracy and the ratio of the identifiable to nonidentifiable fragments when microhistological analysis was used. Soaking sample material in either sodium hydroxide or bleach improved accuracy compared to use of standard sample preparation techniques described by Sparks and Malechek (1968). The improved accuracy was attributed to the removal of pigments associated with certain forb and shrub species that make identification of epidermal material difficult. Use of microhistological analysis may result in poor estimation of certain browse species because leaves from these species have a low proportion of epidermal material in relation to total biomass (Westoby et al. 1976). Correlation coefficients between observed and expected values for dietary species were low in Westoby's investigation indicating that regression would be an unsatisfactory means of correcting data. In contrast, Holechek and Gross (1982a) and Holechek et al. (1982a) found browse species were accurately estimated in their studies. Only current years growt h of browse was used, and observers were replicated and required to pass an intensive training program in the studies of Holechek and Gross (1982a) and Holechek et al. (1982a). Vavra and Holechek (1980) found that sample preparation partially destroyed one shrub species used in hand compounded diets. Epidermal fragments of forbs can also be destroyed during sample preparation (Rogerson et al. 1976). Several studies now show that hand compounded diets should be used in all studies involving microhistological analysis to test the assumption of a one to one ratio between actual and estimated diet percent by weight composition (Westoby et al. 1976, Rogerson et al. 1976, Havstad and Donart 1978, Vavra and Holechek 1980, Agruirre-De Luna et al. 1981, Holechek 1982, Holechek and Gross 1982a, Holechek et al. 1982a). Regression analysis can be used for correction if certain species do not exhibit this ratio (Vavra and Holechek 1980).

Holechek et al. (1982a) examined the influence of plant growth stage on the results from microhistological analysis. They used hand compounded diets containing equal proportions of grasses, forbs and shrubs. Mature and immature growth stages were compared for diets having the same botanical composition. Little difference was found between the two stages of maturity for most of the species that were studied. Holechek and Gross (1982a) used combinations of mature and immature plants to evaluate the accuracy of microhistological analysis. Stage of maturity appeared to have little or no influence on results.

Research has shown that the precision of microhistological analysis is a function of the number of frequency observations recorded per slide rather than the number of fields examined per slide (Holechek and Vavra 1981). At least 20 frequency observations should be recorded per slide in order to maintain repeatability between slides. The numbers of slides required for different levels of precision when this restriction is met are provided by Holechek and Vavra (1981).

Holechek and Gross (1982b) found the conversion of frequency to density by the Fracker and Brischle (1944) table was less accu- 
rate and more time consuming for obtaining diet percent by weight composition than a more simple procedure. The alternative procedure involves adding the total number of frequency observations for all species. The number of frequency observations of each species is divided by the total number of frequency observations for all species. This number multiplied by 100 is used as the percent by weight composition of the diet.

Variation associated with observers was reported in studies by Holechek and Gross (1982a) and Holechek et al. (1982a). Both studies showed that observers were fairly consistent in their estimates of hand compounded diets if given previous specialized training. However, Holechek et al. (1982a) found that estimations from an experienced observer not given specialized training were both inconsistent with observers receiving such training and much lower in accuracy. The average coefficient of variation associated with four trained observers was $17 \%$ when they evaluated 26 hand compounded diets comprised of various combinations of 30 different forage species in a study by Holechek and Gross (1982a). Holechek et al. (1982a) recommended that observers should be replicated if the study objective is to accurately quantify herbivore diets using microhistological analysis. However, if only relative differences between herbivore species and dietary trends are of interest, this is probably not necessary, particularly if the procedures described by Holechek and Gross (1982a) are used to train and evaluate observers

A new procedure called infrared reflectance (IR) has been used effectively to evaluate the nutritive value of herbivore diet samples (Norris et al. 1976, Ward 1980). The principles behind IR are discussed by Norris et al. (1976) and Stermer et al. (1977). A review of the procedure is provided by Shenk et al. (1979). Preliminary research has shown that the botanical composition of grass-legume mixturcs can be predicted within 10 percent of the mean using IR (Shenk et al. 1979). IR may hve potential for botanical analysis of fecal and fistula samples from range herbivores.

\section{Summary and Future Research Needs}

The methods presently available to estimate range herbivore diet botanical composition all have important limitations. Utilization studies for diet determination are most suitable for winter ranges having dormant plants that are used primarily by one species of herbivore. If direct observation is used in conjunction with tame animals, it can give accurate results. Fecal analysis has largely replaced stomach analysis as a procedure to evaluate wild herbivore diets. This has been because fecal analysis gives greater sampling precision and does not require animal sacrifice. Differential digestion reduces accuracy with either stomach or fecal procedures but information can be obtained on what species are being consumed. The use of microdigestion and regression procedures with known diets has considerable potential to correct this problem. An additional disadvantage of fecal analysis is that it requires large labor inputs. Despite its limitations, fecal analysis is the method of choice for evaluating wild herbivore diets in many situations. Diet samples most representative of what the range animal has actually consumed are provided with fistula techniques. The esophageal fistula provides a sample more representative of the actual diet than the rumen fistula and also requires less labor. Poor precision and expense are major problems associated with fistula procedures. In addition fistula techniques are difficult to use with wild ruminants. Several techniques have been developed to estimate botanical composition of masticated forages or fecal droppings. However, only the microscope point and the microhistological techniques provide quantitative results. Research is available showing both techniques can provide reasonably accurate estimates of herbivore diets on the basis of percent composition by weight. The microscope point technique requires less sample preparation than microhistological analysis but its application is restricted to masticated forages. Relating microscope points to volume rather than weight may give more accurate results. Hand compounded diets are essential for training observers and checking observer accuracy when microhistological analysis is used.

Presently research is needed in comparing the microscope point and microhistological techniques. The microscope point method may be more suitable for analysis of fistula samples than microhistological analysis because less time is required and problems associated with sample preparation are reduced. However, this has not been studied. Much more research is needed evaluating the accuracy of fecal analysis. Although microdigestion procedures look promising as a means to correct for differential digestion, their actual effectiveness has not been established. Information on the precision of fecal sampling is limited to one study involving deer, and necds further study. Infrared reflectance is a new procedure used for analysis of forage nutritive value that may have potential for evaluating the botanical composition of fecal and fistula samples. This should be investigated.

\section{Literature Cited}

Aguirre-De Luna, R., P.R. Ogden, and E.L. Smith. 1981. Accuracy of the microhistological technique of fecal analysis for diet determination. Abstr, if 34th Annual Meeting, Soc. Range Manage. p. 1.

Anderson, Allen E., W.A. Snyder, and George W. Brown. 1965. Stomach content analyses related to condition in mule deer, Guadalupe Mountains, N. Mex. J. Wildl. Manage. 29:352-366.

Anthony, R.G., and N.S. Smith. 1974. Comparison of rumen and fecal analysis to describe deer diets. J. Wildl. Manage. 38:535-540.

Arnold, G.W., and M.L. Dudzinski. 1978. Ethology of free-ranging domestic animals. Elsevier Scientific Publishing Company. New York, New York. 198 p.

Baker, E.W., and B.W. Wharten. 1952. An introduction to acarology. MacMillan Co., New York. 465 p.

Bath, D.L., W.C. Weir, and D.T. Torell. 1956. The use of the esophageal fistula for the determination of consumption and digestibility of pasture forage by sheep. J. Anim. Sci. 15:1166-1171.

Baumgartner, L.L., and A.C. Martin. 1939. Plant histology as an aid in squirrel food-habit studies. J. Wildl. Manage. 3:266-268.

Bedell, T.E. 1968. Seasonal preferences of grazing cattle and sheep in western Oregon. J. Range Manage. 21:291-297.

Bergerud, Arthur T., and Lloyd Russell. 1964. Evaluation of rumen food analysis for Newfoundland caribou. J. Wildl. Manage. 29:813-819.

Bjugstad, Ardell J., H.S. Crawford, and Donald L. Neal. 1970. Determining forage consumption by direct observation of domestic animals. In: Range and Wildl. Habitat Eval.-A Res. Symp. U.S. Dep. Agr. Forest Serv. Misc. Pub. No. 1147. 220 p.

Brown, Ellsworth R. 1961. The black-tailed deer in western Washington. Washington State Game Dep. Biol. Bull. 13, 124 p.

Buchanan, H., W.A. Laycock, and D.A. Price. 1972. Botanical and nutritive content of the summer diet of sheep on a fall forb range in southwestern Montana. J. Anim. Sci. 35:423-428.

Campbell, C.M., K.S. Eng Jr., A.B. Nelson, and L.S. Pope. 1968. Use of esophageal fistula in diet sampling with beef cattle. J. Anim. Sci. 30:231234.

Casebeer, R.L., and G.G. Koss. 1970. Food habits of wildebeest, zebra, heartbeest and cattle in Kenya Masailand. E. Afr. Wildl. 8:25-36.

Chamrad, A.D., and T.W. Box. 1964. A point frame for sampling rumen contents. J. Wildl. Manage. 28:473-474.

Chamrad, A.D., and T.W. Box 1968. Food habits of white-tailed deer in south Texas. J. Range Manage. 21:158-164.

Chapman, H.W., and F.J. Hamilton. 1962. Esophageal fistulation of calves. Aust. Vet. Jour. 38:400 (note).

Chippendale, G. 1962. Botanical composition of kanga roo and cattle stomach contents. Aust. J. Sci. 25:21-22.

Connor, J.M., V.R. Bohman, A.L. Lesperance, and F.E. Kinsinger. 1963. Nutritive evaluation of summer forage with cattle. J. Anim. Sci. 22:961966.

Cook, C.W., and L.A. Stoddart. 1953. The quandry of utilization and preference. J. Range Manage. 6:329-335.

Cook, C.W., J.L. Thorne, J.T. Blake, and J. Edlefsen. 1958. Use of an esophageal fistual cannula for collecting forage samples by grazing sheep. J. Anim. Sci. 17:189-193.

Cook, C.W., J.T. Blake, and J.W. Call. 1963. Use of esophageal fistula cannula for collecting forage samples from both sheep and cattle grazing in common. J. Anim. Sci. 22:579-581.

Courtright, A.M. 1959. Results of some detailed analyses of caribou rumen contents. Tenth Alaskan Sci. Conf. Proc. 1959:28-35. 
Croker, B.H. 1959. A method for estimating the botanical composition of the diet of sheep. N.Z.J. Agr. Res. 2:72-85.

Dearden, B.L., R.E. Pegau, and R.M. Hanse. 1975. Precision of microhistological estimates of ruminant food habits. J. Wildl. Manage. 39:402407 .

Denham, A.H. 1965. In vitro fermentation studies on native sandhill range forage as related to cattle preference. M.S. Thesis, Colorado State Univ., Fort Collins. $78 \mathrm{p}$.

Dunnet, G.M., A.E. Harvie, and J.T. Smit. 1973. Estimating the proportion of various leaves in the diet of the opossum, Trichosupus vulpecula Kerr, by faecal analysis. J. Appl. Ecol. 10:737-745.

Durham, Albert J., and M.M. Kothmann. 1977. Forage availability and cattle diets on the Texas Coastal prairie. J. Range Manage. 30:103-106.

Dusi, J.L. 1947. Methods for the determination of food habits by plant micro technique and histology and their application to cottontail rabbit food habits. J. Wildl. Manage. 13:295-298

Edlefsen, J.L., C.W. Cook, and J.T. Blake. 1960. Nutrient content of the diet as determined by hand-plucked and esophageal fistula samples. J. Anim. Sci. 19:560-563.

Fracker, S.B., and J.A. Brischle. 1944. Measuring the local distribution of Ribes. Ecology 25:283-303.

Free, J.C., R.M. Hansen, and P.I. Sims. 1970. Estimating dry weights of food plants in feces of herbivores. J. Range Manage. 23:300-302.

Free, J.C., P.L. Sims, and R.M. Hansen. 1971. Methods of estimating dry-weight composition in diets of herbivores. J. Anim. Sci. 32:10031008.

Galt, H.D. 1972. Relationship of the botanical composition of steer diet to digestibility and forage intake on desert grassland. Unpublished Ph.D. dissertation. Univ. of Arizona, Tucson.

Galt, H.D., P.R. Ogden, J.H. Ehrenreich, B. Theurer, and S.C. Martin. 1968. Estimating botanical composition of forage samples from fistulated steers by a microscope point method. J. Range Manage. 21:397. 401.

Galt, H.D., B. Theurer, J.H. Ehrenreich, W.H. Hale, and S.C. Martin. 1969. Botanical composition of diet of steers grazing a desert grass range. J. Range Manage. 22:14-19.

Grelen, H.E. 1967. Comparison of cage methods for determining utilization on pine-bluestem range. J. Range Manage. 20:94-96.

Grimes, R.C., and B.R. Watkins. 1965. The botanical and chemical analysis of herbage samples obtained from sheep fitted with esophageal fistulae. J. Brit. Grasslands. Soc. 20:168-170.

Hamilton, F.J., W.R. McManus, and L.H. Larsen. 1960. An improved method of esophageal fistulation for food intake studies in sheep. Aust. Vet. J. 36:111-112.

Hansen, R.M. 1971. Estimating plant composition in wild sheep diets. First Trans. North Amer. Wild Sheep Conf. 180-185

Harker, K.W., D.T. Torell, and G.M. Van Dyne. 1964. Botanical examination of forage from esophageal fistulas in cattle. J. Anim. Sci. 23:465-469.

Harniss, R.0., D.A. Price, and D.C. Tomlin. 1975. Number of fistula samples needed for determination of sheep diet on sagebrush-grass range. J. Range Manage. 28:417-419.

Havstad, K.M., and Gary B. Donart. 1978. The microhistological technique: testing two central assumptions in south central New Mexico. J. Range Manage. 31:469-470.

Heady, Harold F. 1957. Effect of cages on yield and composition in the California annual type. J. Range Manage. 10:175-177.

Heady, H.F., and D.T. Torell. 1959. Forage preferences exhibited by sheep with esophageal fistulas. J. Range Manage. 12:28-33.

Heady, H.F., and G.M. Van Dyne. 1965. Prediction of weight composition from point samples on clipped herbage. J. Range Manage. 18:144-149.

Hill, R.R. 1946. Palatability ratings of Black Hills plants for white-tailed deer. J. WildI. Manage. 10:47-54.

Hoehne, O.E., D.C. Clanton, and C.L. Streeter. 1967. Chemical changes in esophageal fistula samples caused by salivary contamination and sample preparation. J. Anim. Sci. 26:628-631.

Holechek, J.L. 1980. The effects of vegetation type and grazing system on the performance, diet and intake of yearling cattle. $\mathrm{Ph}$. D. Thesis, Oregon State Univ., Corvallis. 247 p.

Holechek, J.L. 1982. Sample preparation techniques for microhistological analysis. J. Range Manage. 35:267-268.

Holechek, J.L., and M. Vavra. 1981. The effect of slide and frequency observation numbers on the precision of microhistological analysis. J. Range Manage. 34:337-338.

Holechek, J.L., and B.D. Gross. 1982a. Training needed for quantifying simulated diets from fragmented range plants. J. Range Manage. 35:(in press).
Holechek, J.L., and B.D. Gross. 1982b. Evaluation of different calculation procedures for microhistological analysis. J. Range Manage. 35:(in press).

Holechek, Jerry L., B.D. Gross, S. Mady Dabo, and T. Stephenson. 1982a. Effects of sample preparation, growth stage and observation on microhistological analysis. J. Wildl. Manage. 46:502-505.

Holechek, J.L., M. Vavra, and R.D. Pieper. 1982b. Methods for determining the nutritive quality of range ruminant diets: a review. J. Anim. Sci. 54:363-376.

Howard, V.W., Jr. 1967. Identifying fecal groups by $\mathrm{pH}$ analysis. J. Wildl. Manage. 31:190-191

Jacobs, J. 1973. A microtechnique ind ex to pronghorn diet and sagebrush coefficients. Job Completion Report, Wyoming Pittman-Robertson Proj. FW-3-R-20. Processed. 49 p.

Jefferies, N.W., and R.W. Rice. 1969. Nutritive value of clipped and grazed forage samples. J. Range Manage. 22:192-196.

Johnson, M.K., and H.A. Pearson. 1981. Esophageal, fecal and exclosure estimates of cattle diets on a longleaf pine-bluestem range. J. Range Manage. 34:232-235.

Kessler, W.B., W.F. Kasworm, and W.L. Bodie. 1981. Three methods compared for a nalysis of pronghorn diets. J. Wildl. Manage. 45:612-618.

Korschgen, L.J. 1966. Foods and nutrition of ruffed grouse in Missouri. J. Wildl. Manage. 30:86-100.

Krueger, William C., William C. Laycock, and Donald A. Price. 1974. Relationships of taste, smell, sight, and touch to forage selection. $\mathrm{J}$. Range Manage. 27:258-262.

Lake, R.P., and D.C. Clanton. 1972. Sampling irrigated pasture with esophageal fistulated steers. Proc. West. Amer. Soc. Anim. Sci. 23: 188191.

Laycock, W.A., H. Buchanan, and W.G. Krueger. 1972. Three methods for determining diet, utilization and trampling damage on sheep ranges. J. Range Manage. 25:352-357.

Lesperance, A.L., E.H. Jensen, V.R. Bohman, and R.A. Madsen. 1960a. Development of techniques for evaluating grazed forage. J. Dairy Sci 43:682-685.

Lesperance, A.L., E.H. Jensen, V.R. Bohman, and R.A. Madsen. 1960b. Measuring selective grazing with fistulated steers. J. Dairy Sci. 43:16151619.

Lesperance, A.L., D.C. Clanton, A.B. Nelson, and C.B. Theurer. 1974. Factors affecting the apparent chemical composition of fistula samples. Univ. of Nevada Agr. Exp. Sta. Bull. T18. 25 p.

Levy, E.B., and E.A. Madden. 1933. The point method of past ure analysis. N.Z. J. Agr. Res. 46:267-269.

Martin, A.C. 1949. Procedures in wildlife food studies. U.S. Fish and Wildl. Serv. Wildl. Leafl. 325,10 p.

Martin, S. Clark. 1970. Relating vegetation measurements to forage consumption by animals. In: Range and Wildl. Habitat Eval.-A Res Symp. U.S. Dep. Agr. Forest Serv. Pub. No. 1147. 220 p.

McInnis, M. 1977. A comparison of four methods used in determining the diets of large herbivores. M.S. Thesis. Oregon State Univ., Corvallis. 127 p.

McManus, W.R. 1962a. Studies on the relationship of saliva to rumen function of sheep on cow feed intakes. Aust. J. Agr. Res. 13:907-923.

McManus, W.R. 1962b. Esophageal fistulation studies in the sheep. Aust. Vet. Jour. 28:85-91.

Medin, D.E. 1970. Stomach content analyses:collections from wild herbivores. p. 133-143. In: Range and Wildl. Habitat Evaluation-A Res. Symp. U.S. Dep. Agr. Forest Serv. Misc. Pub. 1147. 220 p.

Norris, J.J. 1943. Botanical analysis of stomach contents as a method of determining forage consumption of range sheep. Ecology. 24:244-251.

Norris, K.H., R.F. Barnes, J.E. Moore and J.S. Shenk. 1976. Predicting forage quality by infra red reflectance spectroscopy. J. Anim. Sci. 43:889896.

Obioha, F.C. 1967. Source of variation in chemical and botanical composition of forage ingested by esophageal fistulated cattle. Ph.D. Diss. Univ. of Nebraska, Lincoln. 153 p.

Owen, M. 1975. An assessment of fecal analysis technique in waterfowl feeding studies. J. Wildl. Manage. 39:271-279.

Owensby, C.E. 1969. Effect of cages on herbage yield in true prairie vegetation. J. Range. 22:131-132.

Reid, E.H., and G.D. Pickford. 1941. A comparison of the ocular-estimateby-plot and the stubble-height methods of determining percentage utilization of range grasses. J. Forest. 39:935-941.

Reppert, J.N. 1960. Forage preference and grazing habits of cattle at the Eastern Colorado Range Station. J. Range Manage. 13:58-62. 
Rice, Richard W. 1970. Stomach content analyses: a comparison of the rumen vs. esophageal techniques. In: Range and Wildl.-Habitat Eval.-A Res. Symp. U.S. Dep. Agr. Forest Serv. Misc. Pub. 1147. 220 p. p.

Ridley, J.R., A.l. Lesperance, E.H. Jensen, and V.R. Bohman. 1963. Relationship of animal preference to botanical composition of irrigated pastures. J. Dairy Sci. 46:128-131.

Rogerson, S.J., E.J. Stevens, and J.G. Hughes. 1976. An improved preparation technique for identification of plant cuticle in animal feaces. N.Z. J. Bot. 14:117-119.

Sanders, K.D., B.E. Dahl, and G. Scott. 1980. Bite-count vs. fecal analysis for range animal diets. J. Range Manage. 32:146-149.

Scotcher, J.S.B. 1979. A review of faecal a nalysis techniques for determining the diet of wild grazing herbivores. Proc. Grassld. Soc. Afr. 14:131136.

Scotter, George W. 1966. Sieve mesh size as related to volumetric and gravimetric a nalysis of caribou rumen contents. Canadian Field-Natur. 80:238-241.

Shenk, J.S., M.O. Westerhaus, and M.R. Hoover. 1978. Analysis of forages by infrared reflectance. J. Dairy Sci. 62:807-811.

Slater, Joanna, and R.J. Jones. 1971. Estimation of the diets selected by grazing animals from microscopic analysis of the faeces. J. Australian Inst. Agr. Sci. 37:238-239.

Smith, D.R., P.O. Currie, J.V. Basile, and N.C. Frischknecht. 1962. Methods for measuring forage utilization and differentiating use by different classes of animals. In: Range Res. Methods Misc. Publ. 940. U.S. Dep. Agr. Forest Serv. p. 93-98.

Smith, A.D., and L.J. Shandruk. 1979. Comparison of fecal rumen and utilization methods for ascertaining pronghorn diets. J. Range Manage. 32:275-279.

Sparks, D.R., and J.C. Malechek. 1968. Estimating percentage dry weights in diets using a microscopic technique. J. Range Manage. 21:264-265.

Stermer, R.A., Y. Pomeranz, and R.J. McGinty. 1977. Inf rared reflectance spectroscopy for estimation of moisture of whole grains. Cereal Chem. $54: 345-347$.

Stewart, D.R.M. 1967. Analysis of plant epidermis in faeces: a technique for studying food preferences of grazing herbivores. J. Appl. Ecol. 4:82-111.

Storr, G.M. 1961. Microscopic analysis of faeces: a technique for ascertaining the diet of herbivorous mammals. Aust. J. Biol. Sci. 14:157-164.
Talbot, L.M., and M.H. Talbot. 1963. The wildebeest in western Maisailand, East Africa. Wildl. Monogr. 12,88 p.

Theurer, C.B. 1970. Determination of botanical and chemical composition of the grazing animals diet. In: Proc. National Conf. Forage Quality Evaluation and Utilization. Nebraska Center for Continuing Education, Lincoln. p. Jl-J17.

Theurer, C.B., A.L. Lesperance, and Joe D. Wallace. 1976. Botanical composition of the diet of livestock grazing native ranges. Univ. Arizona Agr. Exp. Sta. Bull. 233. 20 p.

Torell, D.T. 1954. An esophageal fistula for animal nutrition studies. J. Anim. Sci. 13:878-882.

Van Dyne, G.M., and D.T. Torell. 1964. Development and use of the esophageal fistula. J. Range Manage. 17:7-19.

Van Dyne, G.M., and H.F. Heady. 1965. Botanical composition of sheep and cattle diets on a mature annual range. Hilgardia 36:465-470.

Van Dyne, G.M., N.R. Brockington, Z. Szocs, J. Duek, and C.A. Ribic. 1980. Large herbivore subsystem. In: Breymeyer, A.I. and G.M. Van Dyne (eds.). Grasslands, systems analysis and man. Cambridge Univ. Press. p. 269-537.

Vavra, M., R.W. Rice, and R.M. Hansen. 1978. A comparison of esophageal fistula and fecal material to determine steer diets. J. Range Manage. $31: 11-13$.

Vavra, M., and J.L. Holechek. 1980. Factors influencing microhistological analysis of herbivore diets. J. Range Manage. 33:371-374.

Voth, E.H., and H.C. Black. 1973. A histological technique for determining feeding habits of small herbivores. J. Wildl. Manage. 37:223-231.

Ward, A.L. 1970. Stomach content and fecal a nalysis. In: Range and Wildl. Habitat Evaluation. A Res. Symp. U.S. Dep. Agr. Forest Serv. Misc. Pub. No. 1147.220 p.

Ward, R.G. 1980. Prediction of range cattle forage intake by infrared reflectance spectroscopy of forage specimens. Ph.D. Thesis. New Mexico State Univ., Las Cruces. 80 p.

Westoby, M., G.R. Rost, and J.A. Weis. 1976. Problems with estimating herbivore diets by microscopically identifying plant fragments from stomachs. J. Mammal. 57:167-172.

Wilson, A.E., S.M. Hirst, and R.P. Ellis. 1977. Determination of feeding preferences in wild ruminants from fecal samples. J. Wildl. Manage. 41:70-75.

Zyznar, E., and P.J. Urness. 1969. Qualitative identifiction of forage reminants in deer feces. J. Wildl. Manage. 33:506-510. 